\title{
Pendekatan Joyful Learning Sebagai Metode Pembelajaran Pendidikan Kependudukan \& Lingkungan Hidup (PKLH) di Madrasah Ibtidaiyah
}

\author{
Suriani Nur \\ Sekolah Tinggi Agama Islam Negeri Watampone, Bone, Indonesia \\ e-mail: nani_suriany@yahoo.com
}

\begin{abstract}
Abstrak
Environmental damage is basically the state of the ecosystem is not in a normal state. Environmental problems arise due to human activities use the environment without regard to sustainability. If there is a disregard for the preservation of the environment, then people will feel the impact, both directly and indirectly. Madrasah as one of the first container and a major in the formation of man of faith and character, should support the Government in implementing education learning population and environment (PKLH). Therefore, in the learning environment needs to be designed such that students can learn the population and the environment in a relaxed, happy, and meaningful, so learning it is fun not a burden. PKLH correspond to the learning objectives, then the effective learning should use a variety of approaches that can be fun and attract the attention of students like Joyful Learning approach.
\end{abstract}

Keywords: Pendidikan Lingkungan Hidup, Joyful Learning

\section{Pendahuluan}

Alam semesta raya dihamparkan Allah Swt. agar dapat menyediakan kebutuhan untuk kelangsungan hidup manusia dan semua makhluk hidup yang ada di dalamnya. Keajaiban kehidupan tercipta dalam sebuah sistem kehidupan yang dinamakan ekosistem. Dalam ekosistem inilah terjadi hubungan antara makhluk hidup dengan makhluk tidak hidup, makhluk hidup dengan makhluk hidup, dan antara makhluk tidak hidup dengan makhluk tidak hidup. Rusaknya salah satu unsur dalam sebuah sistem akan berpengaruh terhadap lainnya, karena ada keterkaitan yang kontinyu.

Alam sekitar manusia yang merupakan lingkungan hidup, sudah banyak mengalami kerusakan, karena tangan manusia sendiri. Persoalan lingkungan muncul berawal dari pandangan manusia tidak tepat terhadap alam, memandang alam sebagai sumber kekayaan, yang selalu siap di eksploitasi kapan dan di mana saja, dan oleh siapa saja, tanpa memperhitungkan keberlanjutan untuk masa depan. Untuk menjamin kelangsungan hidup kita dan kelangsungan hidup generasi yang akan datang, dalam suasana baik dan menyenangkan serta untuk menjamin kelangsungan berbagai lapisan kehidupan yang ada di alam, maka manusia harus merubah cara memandang dan memperlakukan alam. Perubahan sikap ini bukan hanya karena alam begitu penting bagi manusia, melainkan karena alam dengan berbagai lapisan kehidupan yang ada di dalamnya, memiliki nilai yang harus dihormati dan dilindungi. 
Masalah kerusakan lingkungan tidak serta merta terjadi dan tidak berdiri sendiri, melainkan terkait dengan banyak hal dan banyak kepentingan yang saling berpengaruh.Masalah lingkungan yang sedang terjadi jauh lebih buruk dan kompleks dari yang dapat dibayangkan. Degradasi lingkungan telah mencapai tahap yang sangat mengkhawatirkan dan sudah pada tingkat mengancam kehidupan. Masalah lingkungan tidak lagi dapat digambarkan dengan tingkat deforestasi, polusi, degradasi lingkungan, banjir, atau fenomena lain yang secara fisik dapat dilihat. Akan tetapi, di balik semua itu terjadi estruksi yang secara sistematis menempatkan manusia dalam risiko yang sangat besar di masa yang akan datang.

Faktor yang sangat penting dalam permasalahan lingkungan ialah besarnya populasi penduduk. Pertumbuhan penduduk yang cepat, kebutuhan akan pangan, bahan bakar, tempat pemukiman dan lain kebutuhan serta limbah domestik juga bertambah dengan cepat. Pertumbuhan penduduk ini telah mengakibatkan perubahan besar dalam lingkungan hidup, terutama di Negara berkembang yang tingkat ekonomi dan teknologinya masih rendah.Kerusakan hutan dan tata air yang disertai kepunahan tumbuhan dan hewan, erosi tanah, serta sanitasi yang buruk ${ }^{1}$. Manusia dapat memanfaatkan sumber daya alam yang ada tetapi mempunyai kewajiban memelihara lingkungan hidup. Oleh karena itu melakukan tindakan preventif (pencegahan) dan kuratif (perbaikan) kerusakan lingkungan hidup merupakan tugas manusia sebagai penyebab kerusakan dan sekaligus yang akan terkena dampak dari kerusakan lingkungan hidup itu sendiri.

Menjaga dan melestarikan lingkungan hidup adalah menjaga kelangsungannya untuk generasi yang akan datang, salah satunya melalui pendidikan. ${ }^{2}$ Agar lingkungan hidup menjadi lestari maka manusia harus memiliki wawasan dan pengetahuan kependudukan dan lingkungan hidup, sehingga sadar dan mampu untuk memelihara kelestarian dan fungsi lingkungan hidup. Pengetahuan mengenai lingkungan hidup diharapkan diberikan sejak dini kepada seluruh lapisan masyarakat dan peserta didik pada semua satuan, jalur jenjang dan pendidikan baik formal, non formal dan informal.

Madrasah Ibtidaiyah sebagai salah satu wadah pertama dan utama dalam pembentukan manusia yang beriman dan berkarakter, maka sejak dini siswa-siswi madrasah ibtidaiyah harus diberikan bekal memadai tentang pengetahuan lingkungan hidup. Sebagai bentuk turut mensukseskan program pemerintah dalam mengimplementasikan pembelajaran pendidikan kependudukan dan lingkungan hidup (PKLH). Oleh karena itu dalam pembelajaran kependudukan dan lingkungan hidup perlu di desain sedemikian rupa sehingga siswa-siswi madrasah ibtidaiyah dapat belajar nyaman, secara santai dan namun bermakna, sehingga belajar itu merupakan hal yang menyenangkan bukan beban. Pembelajaran PKLH yang efektif, seyogyanya menggunakan berbagai macam pendekatan yang dapat menyenangkan dan menarik perhatian siswa, salah satunya menggunakan pendekatan Joyfull Learning.

\footnotetext{
${ }^{1}$ Soemarwoto. Ekologi dan Pembangunan.(Jakarta: Djambatan, 2011). h.23

2 Muhaimin. Membangun Kecerdasan Ekologis Model Pendidikan Untuk Meningkatkan Kompetensi Ekologis. (Bandung: Alfabeta, CV, 2015) h. 19
} 


\section{Pembahasan}

Pembelajaran secara sederhana dapat diartikan sebagai sebuah usaha mempengaruhi emosi, intelektual, dan spiritual seorang agar mau belajar dengan kehendaknya sendiri. Melalui pembelajaran akan terjadi proses pengembangan moral keagamaan, aktivitas, dan kreativitas peserta didik melalui berbagai interaksi dan pengalaman belajar. Pembelajaran berbeda dengan mengajar yang pada prinsipnya menggambarkan aktivitas guru, sedangkan pembelajaran menggambakan aktivitas peserta didik $^{3}$. Proses pembelajaran merupakan kegiatan yang dilakukan untuk terjadinya transfer ilmu dan pengetahuan kepada peserta didik. Pembelajaran akan berlangsung di Madrasah ibtidaiyah, jika ada pendidik yaitu guru dan ada peserta yang akan dididik yaitu siswa.

Pembelajaran merupakan kegiatan yang sengaja direncanakan maka diperlukan pendekatan yang tepat untuk merancang kegiatan pembelajaran yang sistematis sehingga dapat dicapai kualitas hasil atau tujuan yang diperlukan.Pembelajaran pada dasarnya merupakan suatu rekayasa yang diupayakan untuk membantu peserta didik agar dapat tumbuh berkembang sesuai dengan maksud dan tujuan penciptaannya. Dalam kontek, proses belajar di sekolah/madrasah, pembelajaran tidak dapat hanya terjadi dengan sendirinya, yakni peserta didik belajar berinteraksi dengan lingkungannya seperti yang terjadi dalam proses belajar di masyarakat (social learning). Proses pembelajaran harus diupayakan dan selalu terikat dengan tujuan (goal based). Oleh karenanya segala kegiatan interaksi, metode dan kondisi pembelajaran harus direncanakan dengan selalu mengacu pada tujuan pembelajaran yang dikehendaki.

\section{Pendidikan Kependudukan \& Lingkungan Hidup dalam Sistem Pendidikan}

Pendidikan Kependudukan \& Lingkungan Hidup PKLH adalah program pendidikan untuk membina anak didik agar memiliki pengertian, kesadaran, sikap, dan perilaku yang rasional serta bertanggung jawab terhadap alam dan terlaksananya pembangunan yang berkelanjutan. Tujuan PKLH adalah agar siswa memiliki pengetahuan, sikap dan perilaku rasional dan bertanggung jawab terhadap masalah kependudukan dan lingkungan hidup. Beberapa sekolah/madrasah menjadikan PKLH bukan mata pelajaran yang berdiri sendiri melainkan mata pelajaran yang di integrasikan keberbagai mata pelajaran dalam kurikulum yang berlaku. Pendidikan Kependudukan \& Lingkungan Hidup pada jalur pendidikan formal dapat ditempuh melalui dua pendekatan yaitu pendekatan monolitik dan integratif.

Pendekatan monolitik adalah pendekatan yang didasarkan pada suatu pemikiran bahwa setiap mata pelajaran merupakan komponen yang berdiri sendiri dalam kurikulum dan mempunyai tujuan tertentu dalam kesatuan yang utuh. Sistem pendekatan ini dapat ditempuh melalui dua cara, yaitu: a). Membangun satu disiplin ilmu baru yang diberi nama PKLH. Nantinya dijadikan mata pelajaran yang terpisah dari ilmu-ilmu lain. b). Membangun paket PKLH yang merupakan mata pelajaran yang berdiri sendiri.

${ }^{3}$ Abuddin Nata. Perspektif Islam Tentang Strategi Pembelajaran. (Jakarta :Prenada Media Group, 2011.) h. 85 
Kelebihan pendekatan monolitik: 1). Mata pelajaran yang berdiri sendiri. 2). Persiapan mengajar lebih mudah dan bahan-bahannya dapat diketahui dari silabus. 3). Pengetahuan yang diperoleh siswa akan lebih sistemasis.4). Waktu yang disediakan dapat secara khusus, pencapaian tujuan bisa lebih aktif. 5). Evaluasi belajar bisa lebih jelas dan mudah. Kelemahan Pendekatan Monolitik: 1). Perlu dibuat silabus sebagai mata pelajaran yang berdiri sendiri sejajar dengan mata pelajaran lain. 2). Perlu menambah tenaga pengajar yang mempunyai spesialisasi dalam Pendidikan Lingkungan Hidup. 3). Kemungkinan menambah beban belajar siswa dari mata pelajaran yang ada sekarang dalam kurikulum.

Pendekatan Terpadu (Integratif) Pendekatan terpadu adalah pendekatan yang didasarkan pemaduan mata pelajaran Pendidikan Lingkungan Hidup dengan mata pelajaran lain. Pendekatan ini dapat ditempuh melalui dua cara, yaitu: 1) Membangun suatu unit atau seri pokok bahasan yang disiapkan untuk dipadukan kedalam mata pelajaran tertentu. 2). Membangun suatu program inti yang bertitik tolak dari suatu mata pelajaran tertentu. Kelebihan Pendekatan Terpadu yaitu: a). Tidak perlu menambah tenaga kerja pengajar khusus dibidang PKLH. b). Makin banyak guru mata pelajaran lain yang terlibat sehingga siswa memperoleh bahan yang lebih banyak. c). Kelemahan pendekatan terpadu yaitu: a). Perlu adanya penataran guru untuk pelajaran PKLH yang dipadukan. b).Perlu mengubah silabus dan jam pelajaran yang telah ada. c). Timbul kesulitan proses untuk memadukan PKLH dengan pelajaran lain. d) Kemungkinan tenggelamnya program PKLH ke dalam mata pelajaran lain dan sebaliknya. e) Keterbatasan waktu yang tersedia dapat menghambat tercapainya tujuan dengan baik.

\section{Integrasi PKLH dengan Ilmu Lainnya}

Susunan pengetahuan yang jadi perpaduan berdasarkan kurikulum yang ada pada sistem persekolahan yang sedang berlaku.Mata pelajaran induk yang dipilih sebagai wadah perpaduan memiliki daya serap yang cukup.Adapun mata pelajaran yang utama sebagai wadah perpaduan adalah Pendidikan Agama, Bahasa Indonesia, IPA, IPS, PENJAS dan Pendidikan Kewarga Negaraan.Proses belajar dan mengajar sebaiknya dilakukan dengan pendekatan lingkungan alam sekitar (PLAS). Dasar filosofis mengajar dengan mengimpelementasikan pendekatan lingkungan alam sekitar adalah dari Rousseau dan Pestalozzi. Jean Jacques Rousseau (1712-1788), mengatakan bahwa kesehatan dan aktifitas fisik adalah faktor utama dalam pendidikan anak-anak. Rousseau percaya bahwa "anak harus belajar langsung dari pengalaman sendiri, dari pada harus mendengarkan dari penjelasan buku". Disini lingkungan sangat berperan penting dalam proses pembelajaran. Johann Heinrich Pestalozzi (1716-1827), seorang pendidik mengatakan bahwa maka dari pada itu, kependudukan mesti berperan aktif dalam upaya menyalamatkan lingkungan diantaranya adalah: 1). Peran sebagai pengelola, bukan penghancur lingkungan. Saat ini, banyak sekali penduduk yang perannya tidak sesuai dengan kenyataan. Yang mestinya menjadi pengelola, malah yang menjadi pengrusaknya.Pohon ditebang, lahan dieksporitasi dan udara dibuat mengandung penyakit. 2). Peran sebagai penjaga, bukan perusak lingkungan. Kalau dalam diri penduduk sudah sadar akan pentingnya lingkungan hidup 
untuk kehidupannya. Maka, mereka akan menjadi penjaga, bukan menjadi perusak demi kepentingan pribadinya.

Pendidikan lingkungan di butuhkan dan harus diberikan kepada anak sejak dini agar mereka mengerti dan kelak tidak merusak lingkungan. Pendidikan lingkungan sangat berpengaruh terhadap kependudukan, diantaranya: Aspek Kognitif, Afektif, dan psikomotorik. 1). Aspek Kognitif. Pendidikan lingkungan mempunyai fungsi terhadap kognitif yakni untuk meningkatkan pemahaman terhadap permasalahan lingkungan kependudukan, selain itu meningkatkan daya ingat, penerapan, analisis, sintesis dan evaluasi terhadap kondisi yang terjadi dalam lingkungan sekitarnya. 2) Aspek Afektif. Sementara itu, Pendidikan lingkungan berfungsi juga dalam aspek afektif, yakni dapat meningkatkan penerimaan, penilaian, pengorganisasian dan karakteristik kepribadian dalam menata kehidupan dalam keselarasan dengan alam.Sehingga, adanya penataan teradap kependudukan dilingkungan hidupnya. 3) Aspek Psikomotor. Dalam aspek psikomotor, fungsi Pendidikan Lingkungan cukup berperan dalam peniruan, manipulasi, ketetapan, artikulasi, dan pengalamiahan dalam tentang lingkungan yang ada disekitar kita, dalam upaya ningkatkan hajanah kebudayaan misalnya.

\section{Berbagai Teori Tentang Pembelajaran}

Belajar adalah proses perubahan tingkah aku individu sebagai hasil dari pengalaman dalam interaksi dengan lingkungan. Belajar bukan hanya menghafal, melainkan suatu proses mental yang tejadi dalam diri seseorang. ${ }^{4}$ Berdasarkan perkembangan yang ada hingga saat ini, paling kurang ada empat macam teori pembelajaran. Keempat macam teori ini dapat dikemukakan yaitu: Teori Konstruktivistik, Operant conditioning, Teori conditioning, Teori connectionism ${ }^{5}$.

Teori Konstruktivistik adalah usaha mengembangkan manusia dan masyarakat yang memiliki kepekaan, mandiri, bertanggungjawab, dapat mendidik dirinya sendiri sepanjang hayat, serta mampu berkolaborasi dalam memecahkan masalah, diperlukan layanan pendidikan yang mampu melihat kaitan antara ciri-ciri manusia tersebut, dengan praktek-praktek pendidikan dan pembelajaran untuk mewujudkannya. Pandangan konstruktivistik yang mengemukakan bahwa belajar merupakan usaha pemberian makna oleh siswa kepada pengalamnnya melalui asimilasi dan akomodasi yang menuju pada pembentukan struktur kognitifnya, memungkinkan mengarah kepada tujuan tersebut.

Proses belajar sebagai suatu usaha pemberian makna oleh siswa kepada pengalamannya melalui proses asimilasi dan akomodasi, akan membentuk suatu konstruksi pengetahuan yang menuju pada kemutakhiran struktur kognitifnya. Konsep belajar menurut teori belajar konstruktivisme yaitu pengetahuan baru dikonstruksi sendiri oleh peserta didik secara aktif berdasarkan pengetahuan yang telah diperoleh sebelumnya. Pendekatan konstruktivisme dalam proses pembelajaran didasari oleh kenyataan bahwa tiap individu memiliki kemampuan untuk mengkonstruksi kembali pengalaman atau pengetahuan

\footnotetext{
4 Rusman. Model-model pembelaajran: Mengembangkan Profesionalisme Guru. (Jakarta: PT.Radja gragindo Persada, 2013) h.134

${ }_{5}$ Ababuddin Nata, Perspektif Islam. hal.87
} 
yang telah dimilikinya. Pertama adalah peran aktif peserta didik dalam mengkonstruksi pengetahuan secara bermakna.Kedua adalah pentingya membuat kaitan antara gagasan dalam pengkonstruksian secara bermakna.Ketiga adalah mengaitkan antara gagasan dengan informasi baru yang diterima. Diharapkan melalui pembelajaran konstruktivisme, peserta didik dapat tumbuh menjadi individu yang penuh kepercayaan diri yang memiliki sifat-sifat antara lain: 1) Bersikap terbuka dalam menerima semua pengalaman dan mengembangkannya menjadi persepsi atau pengetahuan yang baru dan selalu diperbaharui; 2) Percaya diri sehingga dapat berperilaku secara tepat dalam menghadapi segala sesuatu; 3) Berperasaan bebas tanpa merasa terpaksa dalam melakukan segala sesuatu tanpa mengharapkan atau tergantung pada bantuan orang lain; 4) Kreatif dalam mencari pemecahan masalah atau dalam melakukan tugas yang dihadapinya

Operant conditioning, Kata operant berasal dari bahasa Inggris yang dapat diartikan sebagai sejumlah perilaku atau respon yang membawa efek terhadap lingkungan yang dekat. Sedangkan 'conditioning' dapat diartikan sebagai sebuah keadaan yang berkaitan dengan waktu.Dalam kegiatan pembelajaran, operant conditioning menjamin respon-respon terhadap stimulasi,.Apabila peserta didik tidak menunjukkan reaksi-reaksi terhadap stimulasi, maka pendidik tidak mungkin dapat membimbing Teori conditioning. Secara harafiah berarti menciptakan keadaan. Teori ini dikembangkan oleh Ivan Pavlop. Dikatakan bahwa suatu perbuatan atau reflex dapat dipindahkan ke perbuatan atau reflex lainnya.

Teori connectionism. Teori pembelajaran 'connectionism' ditemukan oleh Edward. Menurut teori ini, bahwa belajar pada dasarnya merupakan sebuah proses asosiasi antar kesan pancaindera dengan impuls untuk bertindak. Asosiasi yang demikian itu, direncanakan sedemikian rupa dan itulah yang selanjutnya dinamakn 'connecting'. Dengan kata lain, bahwa pada dasarnya belajar itu adalah suatu proses pembentukan hubungan yang intens dan interaktif antara stimulus dengan respons, atau antara aksi dan reaksi ${ }^{6}$.

\section{Pembelajaran Pendidikan Kependudukan dan Lingkungan Hidup (PKLH)}

Pendidikan Kependudukan dan Lingkungan Hidup (PKLH) merupakan pendidikan tentang lingkungan hidup dan kependudukan. Berdasarkan kesepakatan bersama No: Kep 07/MENLH/06/2005 dan No. 05/VI/KE/2005 antara menteri pendidikan Nasional dan Menteri Lingkungan Hidup pada tanggal 31 juni 2005 tentang Pembinaan dan pengembangkan pendidikan lingkungan hidup. Harapan agar sumberdaya manusia Indonesia memiliki wawasan dan pengetahuan lingkungan sehingga sadar dan mampu untuk memelihara kelestarian dan fungsi lingkungan hidup. Melalui regulasi ini maka pengetahuan mengenai lingkungan hidup diharapkan diberikan sejak dini kepada seluruh lapisan masyarakat dan peserta didik pada semua satuan, jalur jenjang dan pendidikan.

PKLH adalah pendidikan lingkungan hidup dalam konteks internalisasi secara langsung maupun tidak dalam membantuk kepribadian mandiri serta pola tindak dan pola

\footnotetext{
${ }^{6}$ Ababuddin Nata, Perspektif Islam. hal.87
} 
piker peserta didik sehingga dapat merefleksikan dalam kehidupan sehari-hari ${ }^{7}$. Lingkungan hidup adalah kesatuan ruang dengan semua benda, daya, keadaan dan makhluk hidup termasuk manusia dan perilakunya yang mempengaruhi kelangsungan perikehidupan dan kesejahteraan manusia serta makhluk hidup lainnya ${ }^{8}$.

Secara filosofis, lingkungan hidup itu sendiri adalah berkenaan dengan permukaan bumi sebagai acuan dan segala aktivitas manusia. Oleh karena bumi merupakan titik tolak dalam berbagai aktivitas manusia, maka konsep lingkungan di bumi dapat diklasifikasikan sebagai sistem yang tertutup yang mendapatkan energi dari matahari, memiliki sumber daya air, udara, dan tanah dengan persediaan yang terbatas untuk kesejahteraan manusia, memiliki kapasitas sistem dan siklus alam, serta memiliki materi atau bahan mentah yang terbatas. Biosfera yang meliputi makhluk hidup dan benda mati dimana manusia yang memiliki peran penting dalam berinteraksi dengan lingkungan alam. Ekonomi dan teknologi yang memberikan kontribusi kepada kesejahteraan manusia dan keberlanjutan lingkungan hidup. Kebijakan lingkungan hidup yang dapat menentukan dalam pengelolaan lingkungan hidup.

Pendidikan Kependudukan Lingkungan Hidup (PKLH) diintegrasikan pada berbagai bidang studi yang mempelajari hubungan antara jasad hidup dengan istilah dan lingkungannya termasuk di dalamnya bidang studi IPA, IPS, ORKES, dan Bahasa dan lain-lain. Berbagai disiplin ilmu tersebut dipandang dalam suatu ruang lingkup serta perspektif yang luas dan saling berkaitan. Pada dasarnya, PKLH merupakan wadah bagi pendekatan interdisipliner dalam mengatasi permasalahan yang berkenaan dengan lingkungan hidup manusia khususnya dan organisme hidup pada umum. Tujuan pembelajaran PKLH itu sendiri adalah pembinaan peningkatan pengetahuan, kesadaran, sikap, nilai dan perilaku lingkungan hidup yang bertanggung jawab. Perilaku dalam hal ini berhubungan langsung dengan niat untuk bertindak. Namun sebelum sampai pada ketetapan bertindak, terdapat beberapa faktor yang mempengaruhi, yaitu: (1) kesiapan dalam bertindak, (2) pengetahuan tentang strategi bertindak, (3) pengetahuan tentang isu, dan (4) faktor-faktor kepribadian sepeti sikap, lokus kontrol, dan tanggung jawab individu. Tugas guru dalam pembelajaran PKLH adalah selain membantu siswa-siswi untuk memiliki niat bertindak yang positif terhadap lingkungan hidup, juga memberikan kondisi yang mendukung ke arah perilaku yang sesuai dengan niat. Hal ini disebabkan, untuk mencapai ke arah keberlanjutan lingkungan hidup, niat saja tidak cukup tanpa perilaku yang mendukungnya. Mengkaji PKLH, tekanan ditujukan terutama untuk menyatukan kembali segala ilmu yang menyangkut masalah kependudukan dan lingkungan ke dalam kategori variabel yang menyangkut kependudukan, energi, materi, ruang, waktu dan keanekaragaman.

\footnotetext{
${ }^{7}$ Agung \& Daryanto. Pengantar Pendidikan Lingkungan Hidup.( Yogyakarta: Gava Media, 2013) h. 13

${ }^{8}$ UU RI No 29 Tahun 2009. Tentang Perlindungan dan Pengelolaan Lingkungan Hidup.
} 


\section{Joyful Learning dalam Pembelajaran PKLH di Madrasah Ibtidaiyah}

Joyfull learning merupakan pendekatan belajar mengajar yang menyenangkan. Belajar adalah kegiatan seumur hidup yang dapat dilakukan dengan cara menyenangkan dan berhasil. Untuk mendukung proses Joyfull Learning maka perlu menyiapkan lingkungan sehingga semua siswa merasa penting, aman, dan nyaman. Ini dimulai dengan lingkungan fisik yang kondusif yang diperindah dengan tanaman, seni dan musik. Ruangan harus terasa pas untuk kegiatan belajar seoptimal mungkin. ${ }^{9}$ Joyfull Learning selama ini dikenal dengan pembelajran aktif, kreatif, efektif dan menyenangkan. Prinsip dari pembelajaran Joyfull Learning adalah membuat suasana pembelajaran menyenangkan sehingga peserta didik aktif, kreatif, merasa nyaman, dan gembira dalam belajar. Mengimplementasikan pembelajaran yang menyenangkan dalam pendidikan kependudukan dan lingkugnan hidup di madrasah ibtidaiyah penting dilakukan agar peserta didik tidak tegang menerima materi, mereka bermain tapi memiliki makna.

Pembelajaran yang efektif seyogianya menggunakan berbagai macam pendekatan yang dapat menyenangkan dan menarik perhatian siswa. Tujuan utamanya adalah membantu siswa untuk belajar dengan senang hati, sehingga belajar itu merupakan hal yang menyenangkan bukan beban. Untuk membantu ingatan siswa banyak digunakan mnemonic dengan beberapa simbol, nyanyian, dan puisi yang menjadi jembatan keledai. Sebagai contoh, dalam mempelajari nama-nama planet di tata surya dengan mnemonic 'MOVE MY SUN' di mana M adalah Merkurius, O dibuang, V Venus, E (Earth) Bumi dan seterusnya. Pluto harus ditambahkan pada bagian akhir. Selain itu, siswa lebih baik diajak turut memecahkan masalah dari pada mendengarkan saja. peserta ddik belajar lebih banyak tentang konsep PKLH jika mereka secara aktif terlibat dalam eksperimen di alam, mendiskusikannya, dan mengaplikasikan dalam kenyataan di kehidupan serta alam sekitar mereka. Konsep dan teori ditemukan dengan sebuah tindakan melalui sebuah perlakuan dilaboratorium ataupun turun langsung mengamati di alam sekitar. Pembelajaran yang dilakukan dengan mencari dan menemukan langsung, akan mudah diingat daripada hanya sekedar menghafal.

Mewujudkan tercapainya tujuan pembelajaran PKLH melalui pendekatan joyfull leaning, maka sebaiknya memperhatikan beberapa faktor yaitu: 1) Kebermaknaan; Pemahaman akan meningkat bila informasi baru dengan gagasan dan pengetahuan yang telah dikuasai oleh murid. Khususnya, istilah dan konsep sering sulit dipahami. Pemahaman tersebut perlu digali melalui pengalaman siswa itu sendiri. 2). Penguatan; terdiri atas pengulangan oleh guru dan latihan oleh siswa. Pengulangan tersebut dan latihan dapat menanggulangi proses lupa. Dalam pendekatan joyful learning, penguatan merupakan yang harus diperhatikan. 3). Umpan balik; kegiatan belajar akan efektif bila siswa menerima dengan cepat tentang hasil-hasil tugas belajar tersebut. Umpan balik sederhana, misalnya koreksi jawaban siswa atas pertanyaan guru selama pelajaran berlangsung, atau koreksi pekerjaan siswa.

Confusius telah memperkenalkan pernyataan bahwa: apa yang saya dengar saya

\footnotetext{
${ }^{9}$ Bobbi De Porter, Quantum Learning (Bandung: Kaifa, 2000), h.8.
} 
lupa, apa yang saya lihat saya ingat, dan apa yang saya lakukan saya paham. Pernyataan ini kemudian dimodifikasi menjadi sebuah belajar aktif. ${ }^{10}$ Konsep belajar aktif mengajak siswa untuk terlibat melakukan, mencari dan menemukan sesuatu konsep atau teori, sehingga dengan menemukan sendiri memudahkan peserta didik utuk mengingat dan paham, selain itu peserta didik merasa bermain tapi mendapatkan makna dari bermain tersebut.

Beberapa model pembelajaran yang dapat mendukung pendekatan Joyful Learning antara lain adalah: Diskusi, Penyelidikan Terbimbing, Model IODE, Model Pemecahan Masalah, Kerja Kelompok dll.

Diskusi. Diskusi memiliki arti yang penting dalam mengembangkan pemahaman. Hal ini disebabkan diskusi membawa siswa menggunakan konsep mereka pelajari serta mengubahnya menjadi bentuk ekspresi yang cukup menyenangkan bagi siswa. Kegiatan diskusi yang menyenangkan dapat terpenuhi dengan (a) Pengelompokan arti istilah dan pernyataan, (b) Mengadakan pemahaman bersama dalam suatu kelompok, (c) Berbagi pengetahuan dan pengalaman, (d) Membantu siswa memahami informasi baru, (e) Mengidentifikasi berbagai opini dan pandangan, dan (f) Bekerja sama dalam pemecahan masalah.

Penyelidikan terbimbing dalam pembelajaran PKLH sangatlah relevan, selain menyenangkan juga peluang bagi murid untuk meneliti apa yang telah mereka pelajari dan menerapkannya pada dunia nyata. Penyelidikan yang terbimbing dapat dilakukan dalam berbagai bentuk, di antaranya adalah mencari tahu tentang siklus air misalnya atau mencari tahu aspek-aspek yang menyebabkan air menjadi tercemar, dan sebagainya. Penyelidikan terbimbing akan efektif jika mengikuti serangkaian langkah berikut: (a) siswa memilih atau diberi topic yang perlu diselidiki atau diteliti, (b) mengumpulkan informasi yang mereka perlukan, (c) menganalisa informasi yang telah mereka kumpulkan, dan (d) menyajikan sebuah laporan tentang temuan-temuan penyelidikan tersebut dapat berbentuk presentasi di kelas, serangkaian gambar, diagram dan grafik dinding, atau laporan tertulis.

Istilah IODE dalam Model IODE merupakan akronim bahasa Inggris untuk intake (Penerimaan), Organization (Pengaturan), Demonstration (Peragaan), dan Expression (Pengungkapan). Keempat huruf tersebut menunjukkan bahwa ada empat jenis kegiatan murid pada urutan kegiatan belajar. Model tersebut merupakan cara belajar alami dalam memperoleh pengetahuan baru dalam bidang studi dan cukup menyenangkan siswa. Sebagai contoh, dalam pembelajaran PKLH adalah topik efek gangguan iklim El Nino yang telah menimbulkan kekeringan yang luas, kegagalan panen dan kebakaran hutan di Indonesia. Penerapan dalam pembelajaran di kelas adalah: a). Penerimaan. Mendengarkan informasi pelajaran, melihat foto, peta dan gambar yang menunjukkan efek-efek El Nino, membaca koran, majalah dan buku, mendengarkan laporan radio dan menonton laporan TV tentang El Nino, mewawancarai petani yang panennya telah dirusakkan oleh El Nino. b). Pengaturan. Memetakan daerah-daerah yang terkena El Nino, tulis laporan tentang petani yang terkena kekeringan, siapkan grafik dan tabel yang menunjukkan kerugian

\footnotetext{
${ }^{10}$ Mel Silbermen. Active Learning. (Yogyakarta: Yayasan Pendidikan Islam, 2002) h. 1
} 
karena hilangnya produksi pertanian dan kerugian karena kebakaran hutan, gabungkan laporan-laporan koran tentang turunnya jumlah orang hutan karena kebakaran hutan dan seterusnya. c). Peragaan. Menjelaskan bagaimana El Nino terbentuk, menggambarkan daerah-daerah dunia yang terkena efek El Nino, serta merangkum pengaruh El Nino terhadap produksi beras, kerugian hutan, hilangnya dan matinya binatang hutan dan seterusnya. d). Pengungkapan. Membuat diagram yang menggambarkan efek El Nino, serta menyajikan dalam pembicaraan di kelas tentang El Nino. Atau juga menulis puisi yang menggambarkan perasaan seorang petani yang terkena kekeringan serta menulis cerita tentang kebakaran hutan dan seterusnya.

Model Pemecahan Masalah dapat digunakan dalam pendekatan Joyful Learning karena dapat menarik minat siswa untuk memecahkan masalah-masalah lingkungan hidup di sekitamya.Seperti, mengapa terjadi banjir, mengapa terjadi wabah kolera, mengapa hutan penting bagi kehidupan manusia, dan sebagainya. Dalam model pemecahan masalah ini, tahap-tahap dalam penyelesaian masalah berbeda-beda sesuai dengan masalah yang bersangkutan, namun secara umum tahapan ini dapat diurutkan yaitu: a). Identifikasi Masalah Tahap ini merupakan pengenalan masalah atau isu yang ada di sekitar siswa. Dalam hal ini siswa dapat dilibatkan untuk mengemukakan masalah-masalah yang mereka lihat dan rasakan b). Survei Masalah Pertimbangan tentang berbagai sudut pandang dan aspek yang terkait dengan masalah guna meningkatkan pengertian tentang masalah tersebut. c). Definisi Masalah Pendefinisian masalah secara tepat akan membantu anakanak untuk menyelesaikan masalah. d) Fokus Masalah Ukuran masalah perlu dipertimbangkan untuk dipahami karena akan mempengaruhi cara penyelesaian yang akan dilakukan; guru memiliki peran penting dalam membantu siswa untuk mengarahkan pada persoalan yang utama. e) Analisis Faktor-Faktor Penyebab. Faktor penyebab harus dicari begitu masalahnya telah diketahui dan ditentukan ukurannya. Karena itu, kita perlu mengembangkan pemahaman murid tentang masalah itu sendiri. f) Pemecahan masalah karena upaya untuk menyelesaikan masalah sering menimbulkan masalah lain. Siswa dalam hal ini sebaiknya diikutsertakan.

Melalui kerja kelompok siswa diberi peluang untuk menentukan tujuan, mengajukan dan menyelidiki, menjelaskan konsep, dan membahas masalah. Kerjasama siswa dapat merangsang pemikiran mereka untuk berbagi gagasan. Menjadi bagian dari suatu kelompok akan menumbuhkan rasa saling memiliki, saling hormat, dan tanggung jawab. Sikap dan perilaku serta keterbukaan pikiran, tanggung jawab, kerja sama, dan perhatian pada orang lain juga dapat dikembangkan. Itu semua adalah keistimewaan penting tentang perilaku kelompok yang efektif. Kerja kelompok yang baik memerlukan persiapan yang cermat dan dipakai hanya: a). Untuk kegiatan yang memiliki sasaran yang jelas dan yang dapat dilakukan dengan lebih baik oleh suatu kelompok dibandingkan oleh perseorangan. b).Untuk kegiatan di mana semua anggota kelompok yang bersangkutan dapat diberi tugas berguna yang harus dilaksanakan. c). Bila semua anggota kelompok tersebut memiliki keterampilan yang diperlukan untuk melaksanakan tugas yang telah diberi kepada mereka. 
Berbagai model pembelajaran yang dapat diimplementasikan untuk pendekatan Joyfull Learning ini, tergantung dari profesionalitas dan kreatifitas seorang pendidik dalam memilih model dan strategi pembelajaran yang cocok dengan situasi, kondisi dan materi yang akan disampaikan sehingga tujuan pembelajaran Pendidikan kependudukan dan lingkungan hidup dapat tercapai.

\section{Cara Menciptakan Joyfull Learning}

\section{Tehnik-tehnik Mengajar Yang Menyenangkan.}

Implementasi pembelajaran yang menyenangkan sangat memudahkan peserta didik dalam menyerap makna dan membangun konsep dari suatu materi pembelajaran, khusunya dalam pembelajaran Pendidikan Kependudukan dan Lingkungan Hidup (PKLH). Tenaga pengajar dalam hal ini guru harus berupaya menciptakan suasana belajar yang menyenangkan.

Adapun upaya yang harus dilakukan oleh guru dalam kegiatan pembelajaran adalah :

a. Mengawali pembelajaran secara menyenangkan. Guru yang mengawali pembelajaran secara menyenangkan akan mengantarkan siswa menyukai materi mata pelajaran yang akan disajikan. Mengintegrasikan ataupun melakukan pembelajaran PKLH secara monolitik dengan menyenangkan akan memudahkan peserta didik untuk mencintai pengetahuan kependudukan dan lingkungan hidup.

b. Menggunakan komunikasi yang positif. Guru harus pandai berkomunikasi positif pada peserta didik. Gaya komunikasi guru kepada peserta didik salah satu penentu proses perkembangan anak, Gaya komunikasi seorang dapat meningkatkan atau membunuh kreatifitas, menumbuhkan rasa percaya diri atau membuat anak tidak percaya diri.

c. Menguasai keterampilan dasar mengajar.

Guru harus pandai menggunakan gaya pembelajaran yang tepat, sesuai dengan kondisi peserta didik. Seorang guru harus terampil dalam membuka dan menutup pelajaran, terampil bertanya, terampil menjelaskan, terampil menggunakan media pembelajaan, terampil menjelaskan materi pelajaran, terampil mengelola kelas, terampil menggunakan berbagai strategi pembelajaran. Seorang guru yang terampil dan menguasai dasar mengajar yang baik memudahkan peserta didik memahami apa yang akan disampaikan pengajar karena dilakukan secara aktif, kreatif dan menyenangkan.

\section{Pengkondisian Lingkungan Belajar}

Pembelajaran yang menyenangkan, membutuhkan persiapan lingkungan yang mendukung siswa merasa penting, aman dan nyaman. Lingkungan yang dimaksud adalah lingkungan fisik dan psikis. Pengkondisian ini ditempuh karena belajar akan efektif jika ada keamanan secara fisik dan emosional dalam diri anak. Lingkungan anak berarti segala situasi fisik yang diciptakan di sekitar ruangan belajar yang meliputi penataan ruang kelas, asesoris kelas, teman, musik dan sebagainya. Pengkondosian lingkungan fisik ini harus dilakukan sedemikian rupa sehingga melahirkan suasana lain bagi anak untuk belajar. Hal 
ini untuk memfasilitasi kebutuhan otak reptil manusia yaitu komponen kecerdasan terendah dari spesies manusia yang bertanggung jawab atas fungsi motorik - sensorik pengetahuan tentang realitas fisik yang berasal dari panca indra. ${ }^{11}$

Sarana dan prasarana salah satu faktor penunjang dalam proses pembelajaran. Meskipun tenaga pengajar sudah handal dalam mentransfer ilmunya, tetapi tidak didukung oleh sarana dan prasarana yang memadai, maka dapat menjadi penghambat dalam pelaksanaan pembelajaran joyfull learning (pembelajaran aktif kreatif dan menyenangkan). Meskipun peserta didik telah diberikan teori tentang lingkungan hidup yang banyak tetapi tidak ditunjang oleh kondisi lingkungan belajar yang kondusif maka juga tidak maksimal hasil yang diharapkan untuk tercapainya tujuan pembelajaran PKLH.

\section{Simpulan}

Bencana lingkungan hidup seperti kebakaran, banjir, longsor dan lainya dapat merusak sumber daya alam. Sekali dimensi kelestarian sumber daya itu mengalami kerusakan akan sulit dipulihkan. Maka penting merealisasikan program Pendidikan Kependudukan dan lingkungan Hidup (PKLH) di madrasah ibtidaiyah, agar sejak usia dini anak-anak memiliki pengetahuan, sikap dan perilaku lingkungan yang mamadai dan tahu menjaga kelestariannya.

Mengembangkan Pendidikan Kependudukan dan Lingkungan Hidup (PKLH) di madrasah ibtidaiyah, dibutuhkan guru yang memiliki kompetensi ekologis yang mampu membangitkan kesadaran kritis peserta didik. Bukan sekedar menghafal suatu konsep dan teori semata, tetapi lebih dari itu agar siswa belajar dengan menyenangkan, gembira dan belajar dengan bermain bermakna terkait lingkungan hidup. Salah satu metode pembelajaran yang dapat diterapkan dalam pembelajaran Pendidikan Kependudukan dan Lingkungan Hidup adalah dengan Pendekatan Joyful Learning.

\section{Referensi}

Bobbi De Porter. Quantum Learning. Bandung: Kaifa, 2000.

Daryanto \& Agung. Pengantar Pendidikan Lingkungan Hidup. Yogyakarta: Gava Media, 2013.

Mel Silbermen. Active Learning. Yogyakarta: Yayasan Pendidikan Islam, 2002.

Muhaimin. Membangun Kecerdasan Ekologis Model Pendidikan Untuk Meningkatkan Kompetensi Ekologis. Bandung: Alfabeta, CV, 2015.

Nata, Ababuddin. Perspektif Islam tentang straegi Pembelajaran. Jakarta: Kencana Prenada Media Group, 2011.

11 Bobbi De Porter, Quantum Learning. h 66. 
Rusman. Model-model pembelaajran: Mengembangkan Profesionalisme Guru. Jakarta: PT.Radja gragindo Persada, 2013.

Soemarwoto. Ekologi dan Pembangunan. Jakarta: Djambatan, 2011.

UU RI N0. 29 Tahun 2009 tentang Perlindungan \& Pengelolaan Lingkungan Hidup 